\title{
IMPACT OF AVERAGE SPEED ENFORCEMENT SYSTEMS ON TRAFFIC SAFETY: EVIDENCE FROM THE ROADS OF LITHUANIA
}

\section{LAURA GAVE்NIENE், LAURA JATEIKIENE் ${ }^{*}$ DONATAS ČYGAS, AISTE் KASPERAVIČIENÉ}

Dept of Roads, Vilnius Gediminas Technical University, Vilnius, Lithuania

Received 27 April 2020; accepted 5 June 2020

\begin{abstract}
Average speed enforcement systems have been used on the roads of foreign countries for many years already, and give a positive effect on reducing accident number. The article presents good practices in the use of average speed enforcement systems in various countries and their impact on improving traffic safety. The article analyses the experience of system installation on the roads of Lithuania and the first results. The article also proposes methodologies for the selection of road sections to be enforced, the equipment used, and distribution of road sections in the road network of Lithuania. A detail analysis is given of the effect of average speed enforcement systems after their installation in three different periods on 25 road sections. The analysed data is differentiated between main and national roads. Conclusions and recommendations are given at the end of the paper for a future development of average speed enforcement systems.
\end{abstract}

Keywords: average speed enforcement systems, road accidents, speeding, traffic rules.

\footnotetext{
* Corresponding author. E-mail: laura.jateikiene@vgtu.lt

Laura JATEIKIENÉ (ORCID ID 0000-0003-2191-4402)

Donatas ČYGAS (ORCID ID 0000-0001-5789-1981)

Copyright (C) 2020 The Author(s). Published by RTU Press

This is an Open Access article distributed under the terms of the Creative Commons Attribution License (http://creativecommons.org/licenses/by/4.0/), which permits unrestricted use, distribution, and reproduction in any medium, provided the original author and source are credited.
} 


\section{Introduction}

Speeding is one of the most frequent violations of traffic rules by the road users. Approximately $50 \%$ of drivers exceed the speed limits (European Commission, 2018; Joint Transport Research Centre, 2006; Yannis, Louca, Vardaki, \& Kanellaidis, 2013). Speeding has been recognised as one of the major causes of road accidents. Speed is a contributing factor to traffic safety, increasing the risk of road accidents (Aarts \& van Schagen, 2006; Finch, Kompfner, Lockwood, \& Maycock, 1994; Kloeden, Ponte, \& McLean, 2001). Speed also has a major effect on accident severity (Elvik, Christensen, \& Amundsen, 2004; Nilsson, 2004).

Speed enforcement has a significant effect on ensuring speed limits. Speed enforcement shall be widely used, easily visible and long-term to continuously warn the drivers about dangerous locations and to motivate them to comply with the speed limit (Liu, Oxley, Corben, \& Young, 2012). A number of drivers are afraid of being penalized; thus, under intensive speed enforcement they comply with the speed limit. Education strengthens the effect of speed enforcement. To make speed enforcement effective, it is important that the drivers understand its need and assess it positively. When drivers are motivated, their compliance with the speed limit is better.

A good practice analysis has confirmed the positive effect of fixed and mobile speed cameras on accident reduction on roads (Carnis \& Blais, 2013; Čygaitè, Lingytè, Andriejauskas, \& Vaitkus, 2013; Goldenbeld \& van Schagen, 2005; Jones, Sauerzapf, \& Haynes, 2008; Kaygisiz \& Sümer, 2019). However, the camera catchment area is limited (Champness, Sheehan, \& Folkman, 2005; De Pauw, Daniels, Brijs, Hermans, \& Wets, 2014a; Li, Graham, \& Majumdar, 2013). The scientific research report of the Norwegian Public Roads Administration (2011) indicates that the largest effect of speed cameras on speed reduction is at the sites of their installation and the effect continues up to $2.5-3.0 \mathrm{~km}$. Mountain, Hirst, \& Maher (2004) have determined that statistically significant reduction of $25 \%$ of fatal and injury accidents is reported up to $250 \mathrm{~m}$ before and up to $250 \mathrm{~m}$ behind the camera site. Having made a comprehensive statistical analysis, Hess (2004), like Mountain, Hirst, \& Maher (2004), has also determined that the largest decrease in the number of fatal and injury accidents is reported within the distance of up to $250 \mathrm{~m}$ on both sides of the camera. With the increasing distance, the effect of camera is decreasing: at a distance of up to $250 \mathrm{~m}$ the number of fatal and injury accidents after installation of speed cameras decreased by $45.74 \%$; up to $500 \mathrm{~m}$ - by $41.30 \%$; up to $1 \mathrm{~km}$ - by $31.62 \%$; up to $2 \mathrm{~km}-$ by $20.86 \%$. Besides, Hess (2004) compared the effect of speed cameras after dividing camera sites according to road type and urban areas or 
outside urban areas. He has determined that speed cameras on A-roads (major roads) perform better than cameras on non-A-roads (minor roads) and speed cameras on outside urban areas (trunk roads) perform better than cameras on urban roads. Liu, Zhang, Wang, \& Xu (2011) have studied the catchment area of speed cameras and determined that drivers start to slow down at a distance of about $300 \mathrm{~m}$ to $400 \mathrm{~m}$ before the camera, and at a distance of about $300 \mathrm{~m}$ to $400 \mathrm{~m}$ behind the camera they reach the initial speed. De Pauw, Daniels, Brijs, Hermans, \& Wets (2014b) have found that installation of speed cameras has a major effect on the reduction in the number of fatal and serious injury accidents at a distance of $250 \mathrm{~m}$ from the speed camera.

Good practice analysis shows that an average speed enforcement system is more efficient on longer road sections than speed camera. Besides, the average speed enforcement system improves traffic flow by reducing speed variation.

The average speed enforcement system is based on the measuring of average speed on a certain road section where the speed limit is constant or variable. At the beginning and end of road section, cameras record the entering and exiting times of vehicle, and its number plate. The duration of time of vehicle detected within the monitored section is compared to the set minimum time duration $t_{1-2}(\mathrm{~s})$, which is calculated according to the section length $l_{1-2}(\mathrm{~m})$ and average speed limit $v_{\mathrm{vid}}$. $(\mathrm{km} / \mathrm{h})$ :

$$
t_{1-2}=3.6 \frac{l_{1-2}}{v_{\text {vid }}} \text {. }
$$

When the vehicle passes the road section faster than the set minimum time duration, the owner of the vehicle is identified based on the vehicle number plate.

In 2014, from all main roads of Lithuania the road A5 KaunasMarijampole-Suwalki reported the largest number of serious accidents per year 9 road users were killed. Therefore, in 2015, the first average speed enforcement system was introduced in Lithuania on $4.873 \mathrm{~km}$ section of the road A5. Since September 2018, there have been 25 average speed enforcement systems on the roads of Lithuania, of which 18 are installed on main roads (the total length of monitored sections is $84.159 \mathrm{~km}$ ), 7 - on national roads (the total length of monitored sections is $19.599 \mathrm{~km}$ ).

The aim of this paper is to determine and to present to the public the impact of average speed enforcement systems installed on the roads of Lithuania. 


\section{Analysis of impact of average speed enforcement systems}

The research results show that there is considerable evidence of a positive influence of the average speed enforcement system on vehicle speed, including average speed, 85th percentile speed, the proportion of speeding vehicle in the traffic flow and speed variability (Soole, Watson, \& Fleiter, 2013). Besides, the average speed enforcement system has a significant impact on the reduction of road accidents within the monitored road section (Vaitkus et al., 2016).

A continuously-operating average speed enforcement system in the Netherlands was first introduced in 2002 on $3 \mathrm{~km}$ section of the motorway A13. At the same time when the average speed enforcement system was introduced, the speed limit was reduced from $100 \mathrm{~km} / \mathrm{h}$ to $80 \mathrm{~km} / \mathrm{h}$. After installation of the system only $0.5 \%$ of vehicles exceeded the speed limit (Wegman \& Goldenbeld, 2006). Installation of the average speed enforcement system resulted in the reduction of $47 \%$ in the number of accidents and $25 \%$ in the number of people killed (Kuratorium fur Verkehrssicherheit, 2007). However, it should be noted that the impact of reduced speed limit on the reduction of accidents together with the installation of the system was not assessed.

In Italy, on the motorway A1 Milan-Naples with the speed limit of $130 \mathrm{~km} / \mathrm{h}$, the average speed enforcement system was activated in 2007. Montella, Persaud, D'Apuzzo, \& Imbriani (2012) determined that the safety effect of the system was statistically significant. Installation of the average speed enforcement system reported a $31.2 \%$ reduction in fatal and injury accidents. The greatest reduction was observed in fatal and serious injury accidents - their number decreased by $55.6 \%$. The system has also a significant effect on the reduction of accidents at curves - a $43.3 \%$ reduction was determined after the system was installed. However, it has been found that the safety effect of the system decreases over time.

The Italian scientists (Montella, Punzo, Chiaradonna, Mauriello, \& Montanino, 2015) studied a long-term effect of average speed enforcement systems in urban area. Analysis of the average driving speed two years after the system was installed showed that the noncompliance with the speed limit over time had increased considerably. According to the scientists, the most likely explanation for this increase is that the average speed control was undertaken only in certain secret periods decided by the police. This could affect the drivers' perception of the risk of speeding. 
In Australia, average speed enforcement systems were started to be used in 2007 on four sections of Hume highway with the length of $8 \mathrm{~km}$, $14 \mathrm{~km}, 7 \mathrm{~km}$ and $25 \mathrm{~km}$. The system detects about 1000 daily offences, and this shows that the detection level of offences is $1 \%$ to $2 \%$ from the daily traffic volume of 50000 to 100000 vehicles (Cameron, 2008).

In Belgium, the researchers (Vanlommel et al., 2015) studied the impact of the average speed enforcement system on the driving speed on two highway sections. The research data showed that the average speed of traffic flow was successfully reduced by $15 \mathrm{~km} / \mathrm{h}$ and became more homogenous.

\section{Algorithm for selecting road sections suitable for the installation of average speed enforcement systems}

The first road sections in Lithuania suitable for the installation of average speed enforcement systems were selected according to the algorithm developed by the Road and Transport Research Institute (2016):

1) when implementing network safety ranking all main and national roads of Lithuania were divided into homogenous sections;

2) from the list of homogenous sections the high accident concentration sections were selected where excessive speed was likely the main cause of accidents;

3) for the selected road section it was assessed if the speed by more than $10 \mathrm{~km} / \mathrm{h}$ is exceeded by more than $10 \%$ of drivers;

4) the selected road sections shall meet the conditions suitable for installing average speed enforcement systems:

a) length of the section shall range from $1 \mathrm{~km}$ to $5 \mathrm{~km}$; thus, the sections can be divided into shorter segments or several sections can be joined. Only in exceptional, reasonable cases the section can be longer or shorter than the indicated;

b) where the section contains junctions or exits the number of vehicles passing through the whole section shall be at least $85 \%$;

c) the section shall have suitable technical possibilities to install the equipment (electricity connection at a $500 \mathrm{~m}$ distance, convenient environment, etc.).

Road sections selected for the installation of average speed enforcement systems on main and national roads of Lithuania were set 
out in priority order. The highest priority was given to the section that satisfied more of the following evaluation criteria:

- there are fatal or injury accidents;

- black spot or high accident concentration section;

- compliance with the type of accident;

- there are people killed or seriously injured;

- traffic volume is high or medium;

- main or national road;

- non-reconstructed section;

- the speed by more than $10 \mathrm{~km} / \mathrm{h}$ is exceeded by more than $10 \%$ of drivers;

- good technical conditions and convenient environment;

- safety of cameras.

At present, road sections suitable for the installation of average speed enforcement systems in Lithuania are selected according to the "Methodology for Selecting and Prioritizing Road Sites Outside Urban Areas to be Installed With Average Speed Enforcement Systems" (Lithuanian Road Administration under the Ministry of Transport and Communications, 2018). Based on this methodology the sections are selected at two stages:

1) all the road sections are divided into homogenous sections;

2) homogenous sections, situated outside urban areas, are assessed according to their conditions suitable for the installation:

- length of the section shall range from $1 \mathrm{~km}$ to $10 \mathrm{~km}$;

- where the section contains junctions or exits the number of vehicles passing through the whole section shall be at least $85 \%$.

Road sections, selected for the installation of average speed enforcement systems outside urban areas, are set out in priority order depending on the following specific criteria.

1. Annual average daily traffic (AADT). Where AADT is 0-399 vehicles per day, the road section is given 5 points, where $400-$ 2199 vehicles per day - 10 points, where $2200-8999$ vehicles per day - 15 points, 9000 and more vehicles per day - 20 points.

2. Accident severity. If on the road section during last 4 years 1 person was killed or injured during road accident, this road infrastructure is given 10 points, if 2 people -20 points, 3 people and more -30 points. If no fatal or injury accidents occurred, the section gets no points.

3. Excessive speed is likely the major cause of road accidents. If on the road section during last 4 years the cause of fatal or injury accident reported by the Traffic Police was excessive speed, the road section is given 30 points. If excessive speed was reported 
as not the main cause of accident or no accidents occurred during last 4 years, the section is given no points.

4. Overtaking restrictions. If on the road section to be provided with the system overtaking is forbidden in the length of $30 \%$ of the road section, the section is given 5 points, in the length of $30 \%$ to $50 \%$ of the road section - 10 points, if overtaking is forbidden in the length of $51 \%$ to $70 \%$ of the road section - 15 points, in the length of $71 \%$ and more -20 points.

Road section that is given more points based on the above-mentioned criteria has a higher priority in the list.

\section{Installation of the average speed enforcement system on main and national roads of Lithuania}

Roads of Lithuania are installed with the average speed enforcement systems TraffiSection VECTOR P2P. The system producers declare that it is a reliable, easy-to-install, networked high technology average speed enforcement system. Based on 20 years of development and operational experience, VECTOR P2P is used to measure automatically the average speed of vehicles along a section of road between the defined entry and exit point (Fig. 1). If the average speed of vehicle is faster than a set threshold, a violation pack of images and meta-data is generated, which is used to enforce the driver who has violated the speed limit.
Laura Gavènienè, Laura Jateikienè, Donatas Čygas, Aistè Kasperavičienè

Impact

of Average Speed Enforcement Systems on Traffic Safety: Evidence From the Roads of Lithuania

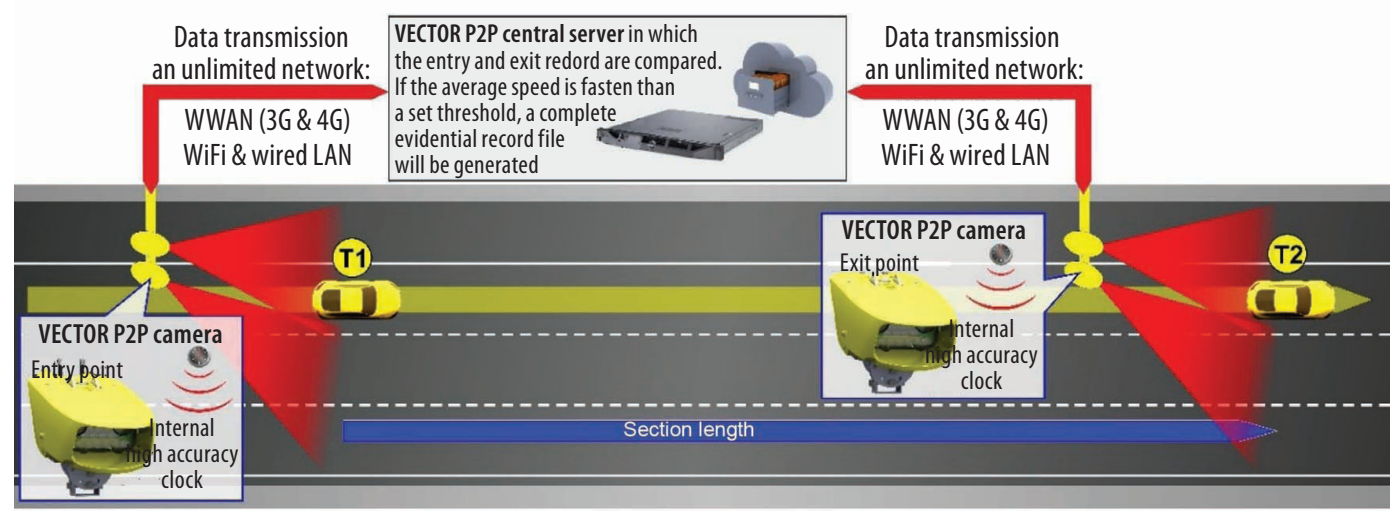

Figure 1. A principle scheme of TraffiSection VECTOR P2P operation 
On main and national roads of Lithuania, the average speed enforcement systems TraffiSection VECTOR P2P were activated in December 2017 and were operating in a testing regime (data were collected but the drivers were not penalized). In August 2018, verification of the systems was carried out by Vilnius Metrology Centre and all the average speed enforcement systems were given verification certificates, indicating that the speed measuring accuracy was: up to 100 $\mathrm{km} / \mathrm{h}-\leq 2 \mathrm{~km} / \mathrm{h}$, more than $100 \mathrm{~km} / \mathrm{h}-\leq 2 \%$. Since 3 September 2018, the systems have been in continuous operation and the speeding drivers have been penalized for the violations of Traffic Rules.

In Lithuania, average speed enforcement systems are operating on 25 road sections of national significance: on main roads there are 18 sections with a total length of $84.159 \mathrm{~km}$, on national roads there are 7 sections with a total length of $19.599 \mathrm{~km}$ (Fig. 2).

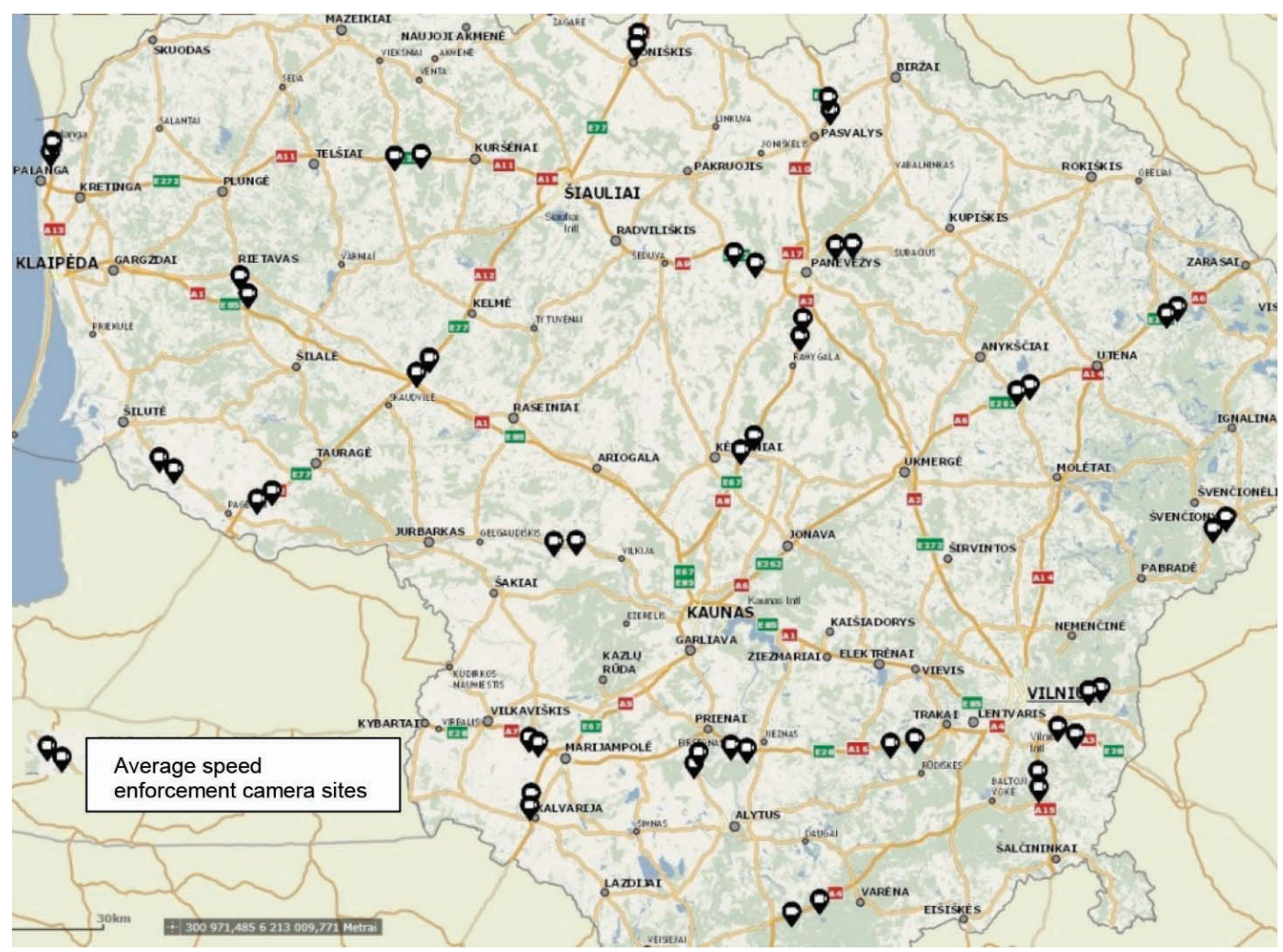

Figure 2. Distribution of the average speed enforcement camera sites on roads of Lithuania 


\section{Analysis of speed data recorded by the average speed enforcement systems}

Having made the analysis of speed data recorded by the average speed enforcement systems using PostgreSQL system, the data were sampled and grouped. Three periods were selected for data grouping: the first - a testing period from December 2017 to February 2018, the second - from December 2018 to February 2019, and the third - from December 2019 to February 2020. For the research, the same winter months from different year were chosen in order to ensure the most similar meteorological traffic conditions.

During the first period, 1887967 vehicles were recorded on the average speed measuring sections. The number of vehicles that exceeded the speed limit up to $20 \mathrm{~km} / \mathrm{h}$, i.e., driving at a speed of $91 \mathrm{~km} / \mathrm{h}$ to $110 \mathrm{~km} / \mathrm{h}$, was 393335 and this made $20.84 \%$ of the total number of the recorded vehicles. Meanwhile, the number of offenders reported to the police authorities and driving at a speed above $110 \mathrm{~km} / \mathrm{h}$ was 39700 and this made $2.10 \%$ (Fig. 3). The remaining vehicles (77.06\%) did not exceed the speed limit in this period. In a testing period when the systems were adjusted not all the days, all of them were active and this was one of the reasons why in the second period more vehicles were recorded.

During the second period, 4959618 vehicles were recorded on the average speed measuring sections. The number of vehicles that exceeded the speed limit up to $20 \mathrm{~km} / \mathrm{h}$, i.e., driving at a speed of $91 \mathrm{~km} / \mathrm{h}$ to $110 \mathrm{~km} / \mathrm{h}$, was 418986 and this made $8.45 \%$ of the total number of the recorded vehicles. Meanwhile, the number of offenders reported to the police authorities and driving at a speed above $110 \mathrm{~km} / \mathrm{h}$ was 8995 and

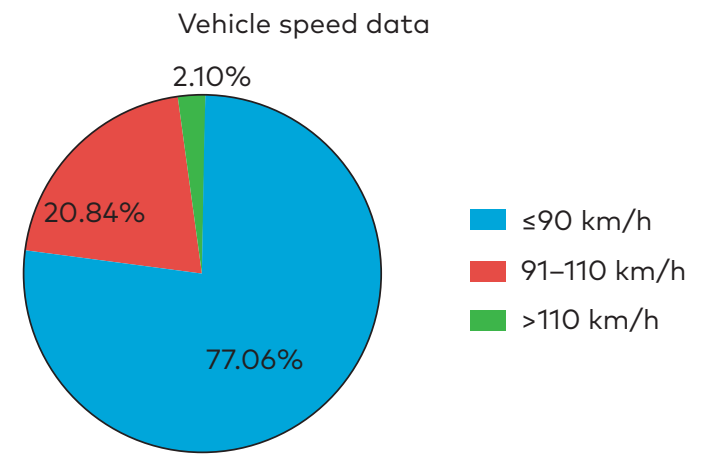

Figure 3. Speed data recorded by the average speed enforcement systems in the period from December 2017 to February 2018 
this made $0.18 \%$. The remaining vehicles $(91.37 \%)$ did not exceed the speed limit in this period (Fig. 4).

During the third period, 6519309 vehicles were recorded on the average speed measuring sections. The number of vehicles that exceeded the speed limit up to $20 \mathrm{~km} / \mathrm{h}$, i.e., driving at a speed of $91 \mathrm{~km} / \mathrm{h}$ to $110 \mathrm{~km} / \mathrm{h}$, was 645873 and this made $9.91 \%$ of the total number of the recorded vehicles. Meanwhile, the number of offenders reported to the police authorities and driving at a speed above $110 \mathrm{~km} / \mathrm{h}$ was 12855 and this made $0.20 \%$. The remaining vehicles $(89.89 \%)$ did not exceed the speed limit in this period (Fig. 5).

Comparison of the speed data from 25 monitored sections showed that the driving behaviour had changed. During the first period, when the average speed enforcement systems operated in a testing regime, the number of vehicles driving at a permissible speed $(90 \mathrm{~km} / \mathrm{h})$ was

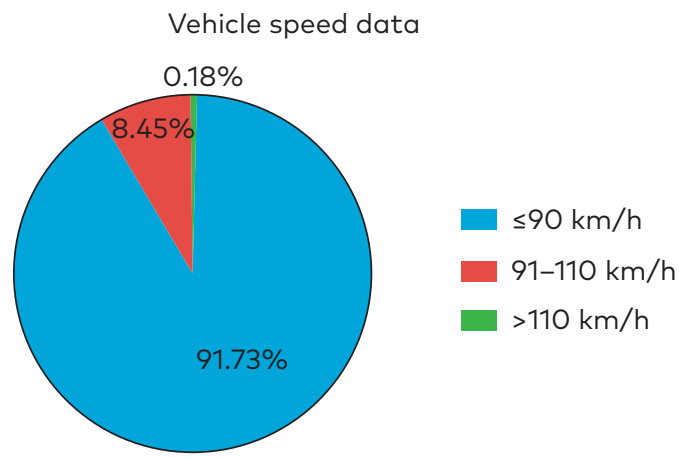

Figure 4. Speed data recorded by the average speed enforcement systems in the period from December 2018 to February 2019

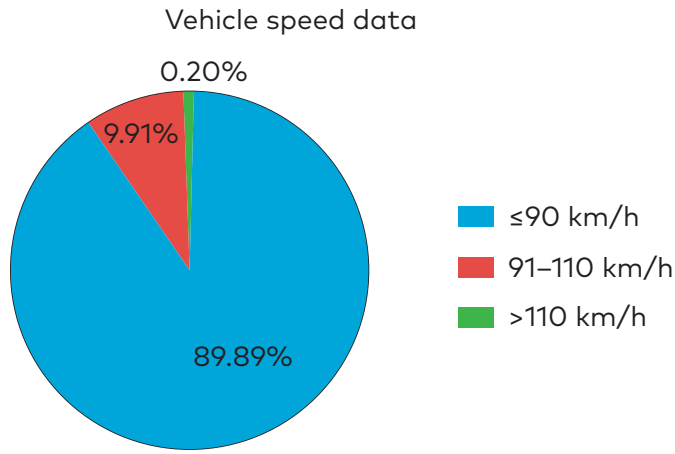

Figure 5. Speed data recorded by the average speed enforcement systems in the period from December 2019 to February 2020 
$77.06 \%$. During the second period, when the average speed enforcement systems operated continuously and the drivers understood that they would be penalized for their speed limit violations, the number of vehicles driving at a permissible speed increased to $91.37 \%$ (Fig. 6). During the third period, when the systems were in continuous operation for more than a year, the number of vehicles driving at a permissible speed was $89.89 \%$, i.e., $12.83 \%$ more than in a testing period. Comparison of the speed data between the first and the third periods indicated that the number of vehicles exceeding the speed limit up to 20 $\mathrm{km} / \mathrm{h}$ decreased from $20.84 \%$ to $9.91 \%$, i.e. by $10.93 \%$. The number of vehicles exceeding the speed limit more than $20 \mathrm{~km} / \mathrm{h}$ decreased from $2.10 \%$ to $0.20 \%$, i.e. by $1.9 \%$.

Comparison of speed data detected by the average speed enforcement systems in the study periods on the roads of different type showed that when the systems operated continuously (during the second and the third periods) the number of vehicles complying with the speed limit $(90 \mathrm{~km} / \mathrm{h})$ was higher on national road sections than on main road sections (Figs. 7 and 8). Also, during a continuous operation of the systems the number of vehicles exceeding the speed limit up to $20 \mathrm{~km} / \mathrm{h}$ and more than $20 \mathrm{~km} / \mathrm{h}$ was less on national road sections compared to main road sections. Comparison of speed data collected in three different study periods showed that on national road sections as well as on main road sections more vehicles complied with the speed limit when the systems operated continuously, not in a testing regime. On main

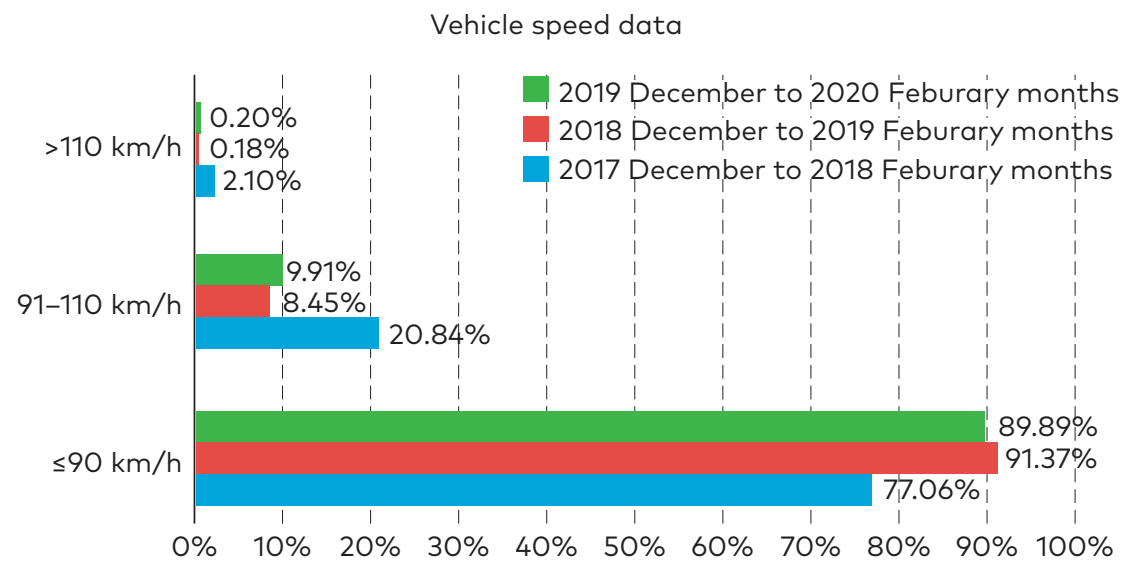

Figure 6. Comparison of speed data recorded by the average speed enforcement systems in the study periods 


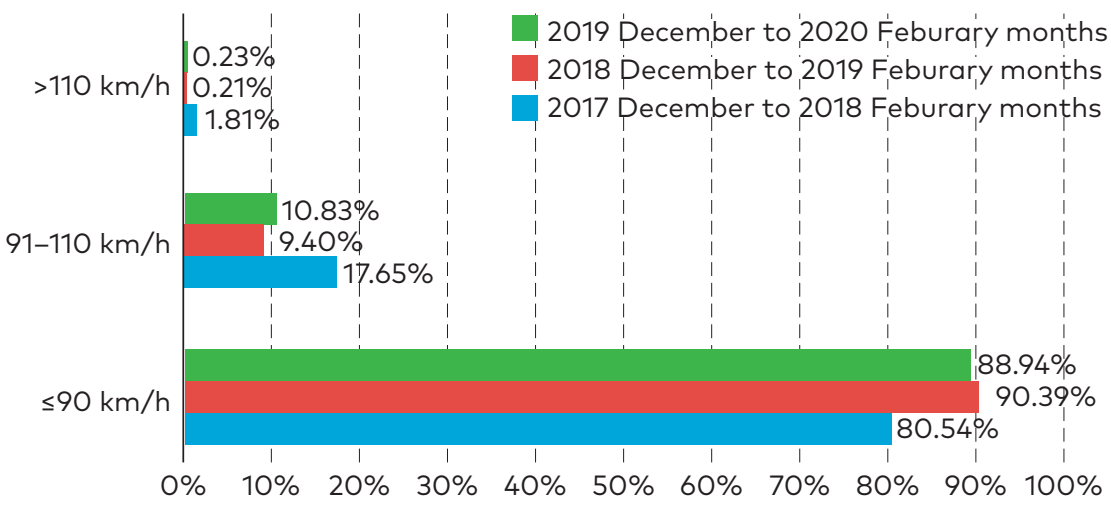

Figure 7. Comparison of speed data recorded by the average speed enforcement systems on main roads in the study periods

Vehicle speed data on national roads

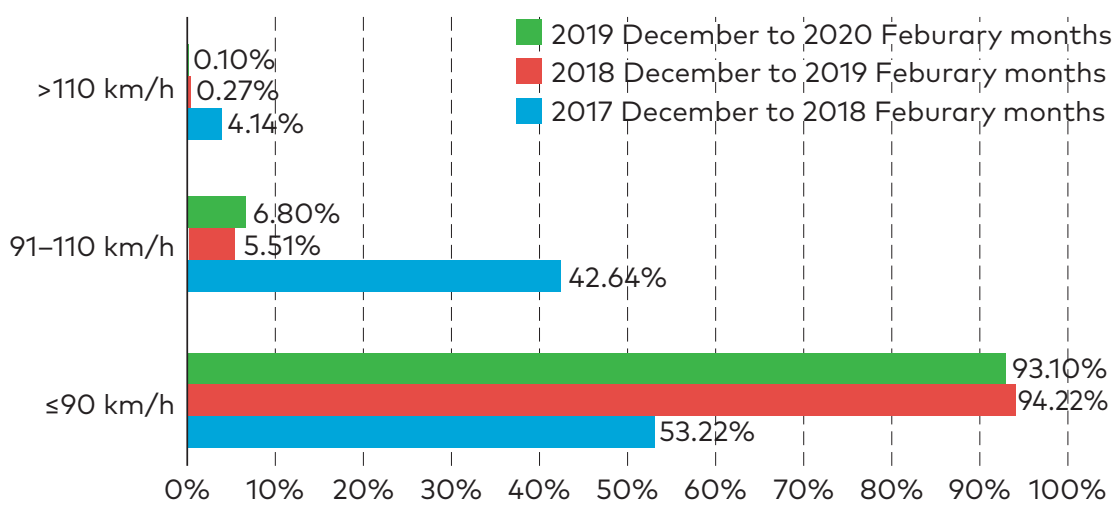

Figure 8. Comparison of speed data recorded by the average speed enforcement systems on national roads in the study periods 
road sections during the second period, compared to a testing period, the number of vehicles complying with the speed limit increased from $80.54 \%$ to $90.39 \%$ (Fig. 7). On national road sections during the second period, compared to a testing period, the number of vehicles complying with the speed limit increased from 53.22\% to $94.22 \%$ (Fig. 8). On main road sections as well as on national road sections the number of vehicles exceeding the speed limit up to $20 \mathrm{~km} / \mathrm{h}$ was less during the second period compared to the third period when the systems were in operation for more than a year. On main road sections in the second period the number of vehicles exceeding the speed limit up to $20 \mathrm{~km} / \mathrm{h}$ made $9.4 \%$ of the total vehicle traffic, while in the third period $-10.83 \%$. On national road sections in the second period the number of vehicles exceeding the speed limit up to $20 \mathrm{~km} / \mathrm{h}$ made $5.51 \%$ of the total vehicle traffic, while in the third period $-6.8 \%$. This could be influenced by the fact that during the study periods penalties for the violations of Traffic Rules were imposed only in case when the speed limit was exceeded by more than $20 \mathrm{~km} / \mathrm{h}$.

\section{Analysis of accident data on the road sections monitored by the average speed enforcement systems}

The fatal and injury accidents reported by the Lithuanian Police on the road sections monitored by the average speed enforcement systems were analysed in two periods:

1) from August 2016 to November 2017;

2) from September 2018 to December 2019.

During the first period, accident data recorded before the installation of the systems were assessed (Table 1).

During the second period, accident data recorded after the installation of the systems were assessed. Both study periods cover 16 months each.

In total, both study periods recorded 22 fatal and injury accidents where 1 person was killed and 37 were injured (Table 1, Fig. 9). 19 of the road accidents are classified as collision or overturning. These types of road accidents usually occur due to speeding. 12 fatal and injury accidents occurred before the installation of the average speed enforcement systems. 10 fatal and injury accidents occurred after the installation of the systems. It has been noticed that during a 16-month operation of the average speed enforcement systems when drivers were aware of the penalties for their speed limit violations, there was 
Table 1. Accident data on the monitored road sections recorded by the average speed enforcement systems

\begin{tabular}{|c|c|c|c|c|c|c|c|c|c|}
\hline \multirow{3}{*}{$\begin{array}{c}\text { Road } \\
\text { number }\end{array}$} & \multirow{3}{*}{$\begin{array}{l}\text { Length of } \\
\text { section, } \\
\text { km }\end{array}$} & \multicolumn{4}{|c|}{$\begin{array}{c}\text { Accident data before } \\
\text { the installation of systems }\end{array}$} & \multicolumn{4}{|c|}{$\begin{array}{c}\text { Accident data after } \\
\text { the installation of systems }\end{array}$} \\
\hline & & \multirow{2}{*}{$\begin{array}{l}\text { Number } \\
\text { of fatal } \\
\text { and injury } \\
\text { accidents }\end{array}$} & \multicolumn{3}{|c|}{ Severity } & \multirow{2}{*}{$\begin{array}{c}\text { Number } \\
\text { of fatal } \\
\text { and injury } \\
\text { accidents }\end{array}$} & \multicolumn{3}{|c|}{ Severity } \\
\hline & & & $\begin{array}{l}\text { Slightly } \\
\text { injured }\end{array}$ & $\begin{array}{c}\text { Seriously } \\
\text { injured }\end{array}$ & Killed & & $\begin{array}{l}\text { Slightly } \\
\text { injured }\end{array}$ & $\begin{array}{c}\text { Seriously } \\
\text { injured }\end{array}$ & Killed \\
\hline A3 & 5.192 & - & - & - & - & - & - & - & - \\
\hline A4 & 8.290 & 1 & 2 & - & - & - & - & - & - \\
\hline A5 & 3.432 & - & - & - & - & - & - & - & - \\
\hline A6 & 2.130 & - & - & - & - & - & - & - & - \\
\hline A6 & 3.403 & - & - & - & - & - & - & - & - \\
\hline A7 & 2.704 & 1 & - & 1 & - & 2 & 6 & - & - \\
\hline A8 & 4.889 & 1 & 1 & - & - & - & - & - & - \\
\hline A8 & 5.240 & - & - & - & - & 2 & 3 & - & - \\
\hline A9 & 6.525 & 2 & 3 & - & - & - & - & - & - \\
\hline A10 & 3.560 & - & - & - & - & 1 & 1 & - & - \\
\hline A11 & 7.119 & - & - & - & - & - & - & - & - \\
\hline A12 & 3.201 & - & - & - & - & - & - & - & - \\
\hline A12 & 5.171 & - & - & - & - & 1 & 1 & - & - \\
\hline A12 & 4.637 & - & - & - & - & 1 & 5 & 1 & - \\
\hline A13 & 2.875 & 1 & 1 & - & - & - & - & - & - \\
\hline A15 & 4.501 & 1 & 1 & - & - & - & - & - & - \\
\hline A16 & 6.865 & 1 & - & - & 1 & - & - & - & - \\
\hline A16 & 4.425 & - & - & - & - & - & - & - & - \\
\hline 102 & 4.748 & - & - & - & - & 1 & 1 & - & - \\
\hline 130 & 3.304 & - & - & - & - & - & - & - & - \\
\hline 141 & 6.186 & - & - & - & - & 1 & 1 & - & - \\
\hline 164 & 5.361 & - & - & - & - & - & - & - & - \\
\hline 103 & 3.696 & - & - & - & - & 1 & 2 & - & - \\
\hline 122 & 4.102 & 3 & 4 & 2 & - & - & - & - & - \\
\hline 141 & 4.976 & 1 & 1 & - & - & - & - & - & - \\
\hline
\end{tabular}

Accident data

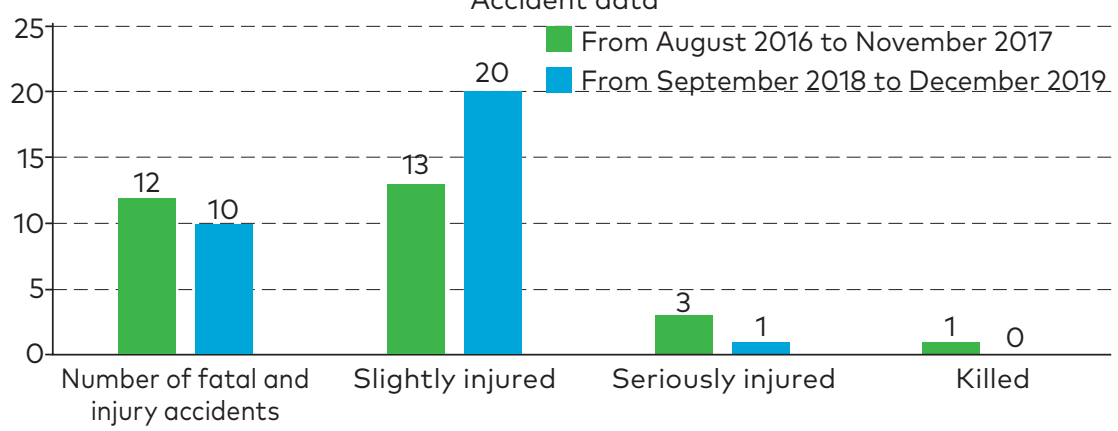

Figure 9. Comparison of accident data in the study periods 
a decrease of $16.67 \%$ in the number of fatal and injury accidents on the monitored 25 road sections in comparison with the data of road accidents, which were reported through 16 month before the installation of the systems. Also, it is noticeable that severity of road accidents recorded after the installation of the systems was slighter than before the installation of the systems (Fig. 9).

\section{Conclusions and recommendations}

1. Analysis of good practices in using average speed enforcement systems on the roads of various countries shows that they have a major effect on the drivers' compliance with the speed limit and reduction in a number of accidents.

2. Comparison of the speed data from 25 monitored sections showed that the driving behaviour had changed. During the first period, when the average speed enforcement systems operated in a testing regime, the number of vehicles driving at a permissible speed $(90 \mathrm{~km} / \mathrm{h})$ was $77.06 \%$. During the second period, when the average speed enforcement systems operated continuously and the drivers understood that they would be penalized for their speed limit violations, the number of vehicles driving at a permissible speed increased to $91.37 \%$ (the increase of $14.31 \%$ ). During the third period, when the systems were in continuous operation for more than a year, the number of vehicles driving at a permissible speed was $89.89 \%$, i.e., $12.83 \%$ more than in a testing period. Comparison of the speed data between the first and the third periods indicated that the number of vehicles exceeding the speed limit up to $20 \mathrm{~km} / \mathrm{h}$ decreased from $20.84 \%$ to $9.91 \%$, i.e. by $10.93 \%$. The number of vehicles exceeding the speed limit by more than $20 \mathrm{~km} / \mathrm{h}$ decreased from $2.10 \%$ to $0.20 \%$, i.e., by $1.9 \%$.

3. Research results showed that the installation of the average speed enforcement system in Lithuania and penalization of offenders allowed reducing the number of accidents on the monitored 25 road sections by $16.67 \%$ in a 16 -month period of its operation in a testing regime.

4. It is recommended to further successfully develop the average speed enforcement systems on main and national roads of Lithuania and to widen a network of monitored sections.

5. Research indicated that in the second period the number of road users driving at a $91-110 \mathrm{~km} / \mathrm{h}$ speed was less than in the third period the increase of $1.46 \%$ was determined. Therefore, it is recommended from time to time to change tolerance of average speed enforcement 
systems towards speeding, assuming that more and more drivers are aware of the limit from which financial penalties are imposed.

6. It is recommended to take account of experience of foreign partners and to reduce the period of issuing and sending a statement of offence of administrative order to speeding drivers.

\section{Acknowledgement}

The authors wish to express their special gratitude to the Lithuanian Road Administration under the Ministry of Transport and Communications for the provided speed data recorded on the average speed enforcement road sections. The authors are also thankful to the public enterprise Transport Competence Agency for the provided accident data on roads of Lithuania.

\section{REFERENCES}

Aarts, L., \& van Schagen, I. (2006). Driving speed and the risk of road crashes: A review. Accident Analysis and Prevention, 38(2), 215-224. https://doi.org/10.1016/j.aap.2005.07.004

Cameron, M. (2008) Development of strategies for best practice in speed enforcement in Western Australia: Supplementary report. Report No. 277. Monash University Accident Research Centre, Victoria, Australia.

Carnis, L., \& Blais, E. (2013). An assessment of the safety effects of the French speed camera program. Accident Analysis and Prevention, 51, 301-309. https://doi.org/10.1016/j.aap.2012.11.022

Champness, P. G., Sheehan, M. C., \& Folkman, L. M. (2005). Time and distance halo effects of an overtly deployed mobile speed camera. In Proceedings of the 2005 Australasian Road Safety Research Policing Education Conference.

Čygaitè, L., Lingytè, I., Andriejauskas, T., \& Vaitkus, A. (2013). Analysis and evaluation of effectiveness of speed calming measures in Lithuanian state roads. In XXVIII International Baltic Road Conference (pp. 1-8). Lithuania, Vilnius, 26-28 August 2013. Vilnius: Baltic Road Association. ISBN 978-6099-55-260-6

De Pauw, E., Daniels, S., Brijs, T., Hermans, E., \& Wets, G. (2014a). Behavioural effects of fixed speed cameras on motorways: Overall improved speed compliance or kangaroo jumps? Accident Analysis and Prevention, 73, $132-140$. https://doi.org/10.1016/j.aap.2014.08.019

De Pauw, E., Daniels, S., Brijs, T., Hermans, E., \& Wets, G. (2014b). An evaluation of the traffic safety effect of fixed speed cameras. Safety Science, 62, 168-174. https://doi.org/10.1016/j.ssci.2013.07.028 
Elvik, R., Christensen, P., \& Amundsen, A. (2004). Speed and road accidents. An evaluation of the Power Model. TØI report 740/2004. Institute of Transport Economics TOI, Oslo.

European Commission. (2018). Speed and speed management 2018. Retrieved from https:/ec.europa.eu/transport/road_safety/sites/roadsafety/files/ ersosynthesis2015-speedspeedmanagement25_en.pdf

Finch, D. J., Kompfner, P., Lockwood, C. R., \& Maycock, G. (1994). Speed, speed limits and crashes. Project Record S211G/RB/Project Report PR 58. Transport Research Laboratory TRL, Crowthorne, Berkshire.

Goldenbeld, C., \& van Schagen, I. (2005). The effects of speed enforcement with mobile radar on speed and accidents: An evaluation study on rural roads in the Dutch province Friesland. Accident Analysis and Prevention, 37(6), 1135-1144. https://doi.org/10.1016/j.aap.2005.06.011

Hess, S. (2004). Analysis of the effects of speed limit enforcement cameras: Differentiation by road type and catchment area. Transportation Research Record: Journal of the Transportation Research Board, 1865(1), 28-34. https://doi.org/10.3141/1865-05

Joint Transport Research Centre. (2006). Speed management. Summary Document. $20 \mathrm{p}$.

Jones, A. P., Sauerzapf, V., \& Haynes, R. (2008). The effects of mobile speed camera introduction on road traffic crashes and casualties in a rural county of England. Journal of Safety Research, 39(1), 101-110. https://doi.org/10.1016/j.jsr.2007.10.011

Kaygisiz, O., \& Sümer, N. (2019). Effects of fixed speed cameras on spatio-temporal pattern of traffic crashes: Ankara case. Journal of Transportation Safety \& Security, 1-19. https://doi.org/10.1080/19439962.2019.1697775

Kloeden, C. N., Ponte, G., \& McLean, A. J. (2001). Travelling speed and the rate of crash involvement on rural roads. Report No. CR 204. Australian Transport Safety Bureau ATSB, Civic Square, ACT.

Kuratorium fur Verkehrssicherheit. (2007). Summary and publication of best practices in road safety in the member states. Thematic Report: Enforcement. European Commission, Austria.

Li, H., Graham, D. J., \& Majumdar, A. (2013). The impacts of speed cameras on road accidents: An application of propensity score matching methods. Accident Analysis and Prevention, 60, 148-157. https://doi.org/10.1016/j.aap.2013.08.003

Lithuanian Road Administration under the Ministry of Transport and Communications. (2018). Methodology for selecting and prioritizing road sites outside urban areas to be installed with average speed enforcement systems. $3 \mathrm{p}$.

Liu, P., Zhang, X., Wang, W., \& Xu, C. (2011). Driver response to automated speed enforcement on rural highways in China. Transportation Research Record, 2265(1), 109-117. http://dx.doi.org/10.3141/2265-12

Liu, S., Oxley, J., Corben, B., \& Young, K. (2012). Velocity series discussion paper 4: factors influencing travel speed. Monash University Accident Research Centre. ISBN 07326 23782. ISSN 1835-4815 (online). 37 p. 
Montella, A., Punzo, V., Chiaradonna, S., Mauriello, F., \& Montanino, M. (2015) Point-to-point speed enforcement systems: Speed limits design criteria and analysis of drivers' compliance. Transportation Research Part C, 53, 1-18. https://doi.org/10.1016/j.trc.2015.01.025

Montella, A., Persaud, B., D’Apuzzo, M., \& Imbriani, L. L. (2012). Safety evaluation of an automated section speed enforcement system. Transportation Research Record, 2281, 16-25. https://doi.org/10.3141/2281-03

Mountain, L. J., Hirst, W. M., \& Maher, M. J. (2004). Costing lives or saving lives: a detailed evaluation of the impact of speed cameras. Traffic Engineering and Control, 45(8), 280-287.

Nilsson, G. (2004). Traffic speed dimensions and the Power Model to describe the effect of speed on safety. Lund Institute of Technology, Lund, Sweden.

Norwegian Public Roads Administration. (2011). Automatic section speed control. Norway. No. 2010: 2625. ISSN: 1892-3844. 56 p.

Road and Transport Research Institute. (2016). Sites for average speed enforcement cameras. Kaunas, Lithuania.

Soole, D. W., Watson, B. C., \& Fleiter, J. J. (2013). Effects of average speed enforcement on speed compliance and crashes: A review of the literature. Accident Analysis and Prevention, 54, 46-56. https://doi.org/10.1016/j.aap.2013.01.018

Vaitkus, A., Strumskys, M., Jasiūnienė, V., Jateikienė, L., Andriejauskas, T., \& Skrodenis, D. (2016). Effect of intelligent transport systems on traffic safety. The Baltic Journal of Road and Bridge Engineering, 11(2), 136-143. https://doi.org/10.3846/bjrbe.2016.16

Vanlommel, M., Houbraken, M., Audenaert, P., Logghe, S., Pickavet, M., \& De Maeyer, P. (2015). An evaluation of section control based on floating car data. Transportation Research Part C, 58, 617-627. http://dx.doi.org/10.1016/j.trc.2014.11.008

Wegman, F. \& Goldenbeld, C. (2006). Speed management: enforcement and new technologies. Report R2006-5, SWOV, Leidschendam.

Yannis, G., Louca, G., Vardaki, S., \& Kanellaidis, G. (2013). Why do drivers exceed speed limits. European Transport Research Review, 5, 165-177.

https://doi.org/10.1007/s12544-013-0097-x

\section{Notations}

Variables and functions

$t_{1-2}$ - set minimum time duration;

$l_{1-2}$ - section length;

$v_{\text {vid. }}$ - average speed limit.

Abbreviations

AADT - Annual Average Daily Traffic. 